\title{
Measuring normal and pathological anxiety-like behaviour in mice: a review
}

\author{
Catherine Belzung ${ }^{\mathrm{a}, *}$, Guy Griebel ${ }^{\mathrm{b}}$ \\ a EA 3248 Psychobiologie des émotions, UFR Sciences et Techniques, Parc Grandmont, Avenue Monge, F-37200 Tours, France \\ b CNS Research Department, Sanofi-Synthelabo, Bagneux, France
}

Received 13 October 2000; accepted 8 February 2001

\begin{abstract}
Measuring anxiety-like behaviour in mice has been mostly undertaken using a few classical animal models of anxiety such as the elevated plus-maze, the light/dark choice or the open-field tests. All these procedures are based upon the exposure of subjects to unfamiliar aversive places. Anxiety can also be elicited by a range of threats such as predator exposure. Furthermore, the concepts of 'state' and 'trait' anxiety have been proposed to differentiate anxiety that the subject experiences at a particular moment of time and that is increased by the presence of an anxiogenic stimulus, and anxiety that does not vary from moment to moment and is considered to be an 'enduring feature of an individual'. Thus, when assessing the behaviour of mice, it is necessary to increase the range of behavioural paradigms used, including animal models of 'state' and 'trait' anxiety. In the last few years, many mice with targeted mutations have been generated. Among them some have been proposed as animal models of pathological anxiety, since they display high level of anxiety-related behaviours in classical tests. However, it is important to emphasise that such mice are animal models of a single gene dysfunction, rather than models of anxiety, per se. Inbred strains of mice, such as the BALB/c line, which exhibits spontaneously elevated anxiety appear to be a more suitable model of pathological anxiety. (C) 2001 Elsevier Science B.V. All rights reserved.
\end{abstract}

Keywords: Anxiety; Mouse; Openfield; Elevated plus maze; Predator-elicited defensive responses; Free exploration test; BALB/c mice

\section{Introduction}

The discovery of benzodiazepines (BZs) in the early sixties and their considerable commercial success in the treatment of anxiety has fueled the development of numerous animal models of anxiety. Unfortunately, because BZs were the only anxiolytic agents marketed at that time, the predictive validity of these initial models has been mainly based on their ability to detect the pharmacological action of BZs. This became evident in the early eighties, when non-BZ anxiolytics, such as the $5-\mathrm{HT}_{1 \mathrm{~A}}$ receptor partial agonist buspirone, were found inactive in some anxiety tests, in particular conflict procedures. At that time, unconditioned conflict tests such as the elevated plus-maze were developed. Later, a second difficulty appeared, when it became

\footnotetext{
* Corresponding author. Tel.: + 33-247-36-6994; fax: + 33-247-367285 .

E-mail address: belzung@univ-tours.fr (C. Belzung).
}

evident that anxiety is not a unitary phenomenon but could be divided in various forms including 'state' and 'trait' anxiety, 'normal' and 'pathological' anxiety. These various forms have been shown to be differentially sensitive to pharmacological challenge. Therefore, when measuring anxiety in animals, it would be useful to have information on the type of anxiety processes which may be involved in a given test. These models are now extensively used not only to predict the clinical efficacy of pharmacological treatments, but also to phenotype the behaviour of transgenic or knockout mice.

The aim of the present paper is to consider animal models of both 'normal' and 'pathological' anxiety. Therefore, we will first give a tentative definition of anxiety, and review the validity criteria of animal models, before presenting animal models of 'normal' and 'pathological' anxiety. Only animal models using mice as subjects will be considered. 


\section{Tentative definition of anxiety}

Fear and anxiety are here, respectively, defined as the response of a subject to real or potential threats that may impair its homeostasis. This response may include physiological (increase in heart rate, blood pressure etc.), as well as behavioural (inhibition of ongoing behaviours, scanning, avoidance of the source of danger, etc.) parameters. When this response is excessive or maladaptive, it involves 'pathological' anxiety. On a clinical level, the DSM IV [25] describes various forms of anxiety disorders, including phobias, generalised anxiety, post-traumatic stress, panic and obsessive-compulsive disorders.

\section{Validity criteria of an animal model}

What is an animal model of a human behavior? According to McKinney, animal models are 'experimental preparations developed in one species for the purpose of studying phenomena occurring in another species' [57]. Kaplan [45] added that a model may be valid if it has the same structure as the human behavior or pathology, that is whenever a relation holds between two elements of the animal model, a corresponding relation may hold between the corresponding elements of the human behavior.

Other authors $[58,84,90]$ have proposed additional criteria. According to them, an animal model should fit predictive validity (pharmacological correlation), face validity (isomorphism) and construct validity (homology and similarity of underlying neurobiological mechanisms) to be suitable for research.

\subsection{Predictive validity}

Predictive validity implies that the animal model should be sensitive to clinically effective pharmacological agents. Conversely, anxiogenic compounds should elicit opposite effects, while agents that have no effect in the clinic should have no effect in these tests.

It is important to note that this involves that a given model may include both variables that are increased by anxiety as well as variables that are decreased by anxiety. For example, when an animal is confronted with a potent source of danger, it displays increased risk assessment behaviours and decreased exploratory activity. In many cases, only the second category of variables are recorded so that an increase in anxiety can be confounded with a non specific inhibition of activity, such as sedation, ataxia, myorelaxation, pre-ictal prostration or even toxic effects induced by the treatment. Many anxiolytics produce such non specific effects: This is particularly striking with BZs which display marked sedative effects at high doses.
Even if the 'predictive validity' criterion seems satisfactory, its relevance can be questioned. Species differences in pharmacokinetic or pharmacodynamic can be observed. For example, in man an important age-related increase of distribution of diazepam has been described, while this does not occur in the same proportions in rats [85]. Furthermore, tachykinin $\mathrm{NK}_{1}$ receptor antagonists have been proposed for the treatment of anxiety. However, species differences have been described in the $\mathrm{NK}_{1}$ receptor pharmacology. For example, the $\mathrm{NK}_{1}$ receptor antagonist, CP-96345 has high affinity for the human receptor, but shows low affinity for the rat $\mathrm{NK}_{1}$ receptor. Furthermore, in the human brain, $\mathrm{NK}_{1}$ receptors are widely expressed throughout areas involved in the modulation of emotional processes, and there is evidence suggesting that $\mathrm{SP}$ is co-expressed with 5-HT, a neurotransmitter involved in anxiety-related processes, whereas co-expression seems to be absent in the rat brain (see [78]). Therefore, $\mathrm{NK}_{1}$ receptor ligands may have different anxiety-modulating properties depending on the species.

\subsection{Face validity}

This criterion implies that the anxiety response observed in the animal model should be identical to the behavioural and physiological responses observed in human. This indicates that the expression of a given emotion is supposed to be similar across species. The physiological expression of anxiety (e.g. increase in heart rate, blood pressure, hyperthermia) is a good example. However, as for the behavioural responses, the patterns much vary across species. The behavioural repertoire of mice is of course very different from the human ethogram, which includes the verbal aspect that is absent in rodents. For example, when confronted with a threat, subjects may tend to escape: the consequence of this behaviour is to avoid the source of danger and consequently to preserve their homeostasis. The behavioural responses used to escape may vary across species: fishes may swim, birds may fly, and human may run. In fact, the possibility of an isomorphism between human and animal behaviours has to be placed in the context of the theory of evolution, suggesting that a given pattern may be selected according to its survival value. It is rather important to note here that natural selection operates on the consequences of the behaviour, rather then on the behaviour per se [81], so that the consequences of the behavioural pattern, rather than the behavioural item per se, may be isomorphic.

\subsection{Construct validity}

This criterion relates to the similarity between the theoretical rationale underlying the animal model and 
the human behaviour. This requires that the etiology of the anxiety behaviour and the biological factors underlying anxiety may be similar in animals and humans.

This criteria seems easy to fulfill for the psychological factors underlying 'normal' anxiety, as in both species this behaviour is induced by a threatening stimulus. It is evident that the nature of the danger may vary across species but the important point is that it causes a threat for the subject's homeostasis. This is not only true for proximal factors of causation but also for distal factors that can contribute to increase subject's sensibility toward threats. For example, impoverishment of the breeding conditions, deficient maternal care during perinatal period or early maternal separation, may induce an increase in anxiety in the individuals when adult, both in animals and in humans $([15,17,86])$. However, this criterion seems rather difficult to fulfill for pathological anxiety as in most cases (except for post-traumatic stress disorder, a disorder defined by its etiology), the psychological factors underlying the disorder have not been described.

\section{4. 'Normal' anxiety and 'pathological' anxiety}

Two rather opposite conceptions have been proposed as to the relationship between the 'normal' and 'pathological' state of a subject. In fact, pathology can be described either as a quantitative variation of a normal state, or as a qualitative variation. According to the first conception, 'pathological' anxiety might be considered as an excess of 'normal' anxiety. The second conception of the relationship between normality and pathology proposes that there is a qualitative, rather than a quantitative variation when passing from the one state to the other. This last conception corroborates that proposed by Canguilhem [16]. In fact, this seems to be the case in anxiety disorders as 'pathological' anxiety rarely includes excess of 'normal' anxiety and as anxiety disorders are not released by the same treatment than 'normal' anxiety.

\section{Mouse models of anxiety}

Over the past three decades, a bewildering diversity of tests has been developed which claim face, construct and/or predictive validity as animal models of anxiety disorders (for review, see [73,89]). While most of these procedures use rats as subjects, a few of them have been validated with mice. Most of them involve exposure of subjects to external (e.g. cues earlier paired with footshock, bright light, predator) or internal (e.g. drug states) stimuli that are assumed to be capable of inducing anxiety in animals. Since none of these models involves pathological anxiety-related behaviors, Lister has described them as animal models of 'state' anxiety [54]. In such procedures, subjects experience anxiety at a particular moment in time and it is increased by the presence of anxiogenic stimulus. The last few years have seen the emergence of models of 'pathological' anxiety, which are often referred to as 'trait' anxiety tests. Unlike 'state' anxiety, 'trait' anxiety does not vary from moment to moment and is considered to be an enduring feature of an individual. As will be shown below, these models either use rodents that were selected for emotional reactivity or employ receptor knockout mice which exhibit phenotypic changes indicative of increased anxiety.

\subsection{Mouse models of 'normal' or 'state' anxiety}

There are several excellent review articles that have described and discussed extensively these models (see, for example, $[54,73,79,84]$ ). Table 1 gives an overview of the existing mouse models of 'state' anxiety. While the vast majority employ behavioral methods, the type of behavior studied varies considerably. They can be grouped into two main subclasses: the first involves animals' conditioned responses to stressful and often painful events (e.g. exposure to electric footshock); the second includes ethologically based paradigms and involves animals' spontaneous or natural reactions (e.g. flight, avoidance, freezing) to stress stimuli that do not explicitly involve pain or discomfort (e.g. exposure to a

Table 1

Mouse models of 'normal' or 'state' anxiety

Conditioned response

Unconditioned response tests

tests
(1) Conflict tests

(a) Operant punishment paradigm

(b) Punished drinking

(2) Others

(a) Active/passive avoidance

(b) Conditioned

(c) Defensive burying ultrasonic vocalization
(1) Exploration tests

(a) Elevated plus-maze

(b) Holeboard

(c) Light/dark choice task

(d) Mirrored chamber

(e) Open field

(f) Staircase test

(g) Zero-maze

(2) Social tests

(a) Agonistic behavior

(b) Separation-induced ultrasonic

vocalizations

(c) Social interaction

(3) Others

(a) Acoustic startle response

(b) Hot plate

(c) Mouse defense test battery

(d) Shock-induced ultrasonic vocalizations

(e) Stress-induced changes in

physiological parameters
Adapted and updated from $[36,73]$. 
novel highly illuminated test chamber or to a predator). The majority of studies using mouse models of 'normal' anxiety employ unconditioned-based procedures. Among these, the elevated plus-maze has become one of the most popular behavioral test for research on anxiety [55,74]. As pointed out by Rodgers [73], this popularity is mainly due to practical rather than theoretical reasons, because the elevated plus-maze permits a quick screening of anxiety-modulating drugs or mouse genotypes without training or involvement of complex schedules. Briefly, in this situation, mice generally taken straight from their home cages, will show a pattern of behavior characterized by open-arm avoidance. This tendency is suppressed by anxiolytics and potentiated by anxiogenic agents. Unfortunately, the plus-maze behavior patterns may be influenced by variations in test parameters (e.g. species, housing conditions, time of testing, lighting level, method of scoring) that do not necessarily become clear, even with close scrutiny of published reports [41]. As a result, the vast literature on the elevated plus-maze yielded inconsistent findings. Serotonin (5-HT)-modulating compounds are particularly prone to discrepancies in the plus-maze. For example, a number of research groups have found that selective 5- $\mathrm{HT}_{1 \mathrm{~A}}$ receptor agonists (e.g. 8-OHDPAT, buspirone) display anxiolytic-like effects in this test $[6,11,53,63,75]$, whereas others have reported a lack of activity [80] or even an anxiogenic-like profile [59]. In this context, Rodgers and Johnson [76] have developed and refined an 'ethological' version of the mouse plusmaze that incorporates specific behavioral postures (e.g. risk assessment, head-dipping) together with conventional spatiotemporal measures of open-arm avoidance. Studies using this modified version of the plus-maze showed that risk assessment measures are generally more sensitive to drug effects than are avoidance measures [73]. For example, comparison between BZ and $5-\mathrm{HT}_{1 \mathrm{~A}}$ anxiolytics revealed differences in anxiolyticlike profiles that may not be detected by conventional scoring. Indeed, while both classes of drugs share the ability to reduce risk assessment, only BZs decrease selectively (i.e. at non motor-impairing doses) open-arm avoidance. Hopefully, the inclusion of ethologicalbased parameters in plus-maze studies may yield more consistent findings than those using the standard version of this test.

Besides the elevated plus-maze, there is a another murine model of 'state' anxiety that uses extensive ethological analysis to generate more comprehensive behavioral profiles following drug treatment, namely the mouse defense test battery (MDTB) [14,35]. The suggestion has been made many times that defensive behaviors of lower mammals constitute a significant model for understanding human emotional disorders [12]. Defensive behaviors occur in response to a number of threatening stimuli, including predators, attacking conspecifics, and dangerous objects or situations. Such behaviors can readily be studied in wild rats, wild mice or in SWISS mice which show a complete defensive repertoire in response to danger. The MDTB consists of an oval runway based on that used in the Fear Defense Test Battery with rats [13]. However, specific situational and behavioral components of the Anxiety Defense Test Battery, involving reactivity to stimuli associated with potential threat rather than to the actual presence of an approaching predator, are incorporated into the mouse battery. Briefly, the MDTB consists of five tests either associated with potential threat (contextual defense) or the actual presence of an approaching threat (i.e. a rat). These latter focus on changes in flight, risk assessment and defensive threat/ attack behaviors, while the former involves escape attempt responses from the runway cage. Drug experiments demonstrated that anxiolytic compounds generally tend to decrease defensive behaviors. However, it is noteworthy that some responses are specifically or mainly affected by certain drug classes [14,37]. Thus, BZs decrease risk assessment activities of animals chased by the rat and defensive threat and attack responses, while 5- $\mathrm{HT}_{1 \mathrm{~A}}$ agents mainly affects contextual defense and defensive threat and attack behaviors. In addition, 5-HT reuptake inhibitors and $\mathrm{CCK}_{\mathrm{B}}$ antagonists have a clearer impact on flight responses than on other defensive reactions. Taken together, these observations suggest that risk assessment, flight, defensive threat/attack and escape attempts probably reflect different aspects of anxiety-related reactions.

A major concern with traditional animal models of 'state' anxiety based on single (mostly spatiotemporal) measures is that they are in most cases unable to discriminate between anxiolysis induced by different classes of anxiolytics (BZs, 5- $\mathrm{HT}_{1 \mathrm{~A}}$ agonists, 5-HT reuptake inhibitors), although clinical findings strongly indicate differential therapeutic efficacy of these agents, according to the anxiety disorder treated. Based on these observations, it is clear that the major advantage of the ethological plus-maze and the MDTB is that they provide models capable of responding to and differentiating anxiolytic drugs of different classes through specific profiles of effect on different measures. This represents a significant improvement over other animal models for evaluating drugs effective against emotional disorders.

\subsection{Mouse models of 'pathological' or 'trait' anxiety}

A review of the literature indicates that nearly thirty new strains of mice have been generated by using gene targeting technology which display a phenotype consistent with increased anxiety (Table 2). While a few of these phenotypes appear to reflect the known function of the target (e.g. 5- $\mathrm{HT}_{1 \mathrm{~A}}$ receptor, corticotropin-releas- 
Table 2

Mouse models of 'pathological' anxiety based on the use of gene targeting technology

\begin{tabular}{|c|c|c|c|c|}
\hline Gene & $\mathrm{Tg}$ or $\mathrm{KO}$ & Genetic background & Models & Reference \\
\hline$\alpha_{4}$ Neural nicotinic acetylcholine receptor & KO & $\operatorname{Mix}(\mathrm{BALB} / \mathrm{c}, \mathrm{C} 57 \mathrm{BL} / 6)$ & EPM & [77] \\
\hline Adenosine $\mathrm{A}_{2 \mathrm{a}}$ receptor & $\mathrm{KO}$ & CD1 & EPM, LD & {$[52]$} \\
\hline \multirow[t]{2}{*}{ Angiotensin II receptor } & $\mathrm{KO}$ & $\operatorname{Mix}(129, \mathrm{C} 57 \mathrm{BL} / 6)$ & EPM, LD & {$[43]$} \\
\hline & $\mathrm{KO}$ & ? & $\mathrm{LD}$ & {$[65]$} \\
\hline Cholecystokinin $_{B}$ receptor & $\mathrm{KO}$ & Mix $(129$, C57BL/6) & EPM & [87] \\
\hline Catechol- $O$-methyltransferase & $\mathrm{KO}$ & $\operatorname{Mix}(129, \mathrm{C} 57 \mathrm{BL} / 6)$ & $\mathrm{LD}$ & {$[30]$} \\
\hline \multirow[t]{2}{*}{ Corticotropin-releasing factor } & $\operatorname{Tg}$ & $\operatorname{Mix}(\mathrm{B} 6, \mathrm{SJL})$ & EPM, LD & [82] \\
\hline & $\mathrm{Tg}$ & Mix (B6, SJL) & LD & [38] \\
\hline \multirow[t]{2}{*}{ Corticotropin-releasing factor binding protein } & $\mathrm{KO}$ & $\mathrm{C} 57 \mathrm{BL} / 6$ & EPM, OF & [71] \\
\hline & $\mathrm{KO}$ & $\mathrm{C} 57 \mathrm{BL} / 6$ & EPM, DF & {$[46]$} \\
\hline \multirow{3}{*}{ Corticotropin-releasing factor $_{2}$ receptor } & $\mathrm{KO}$ & $\operatorname{Mix}(129, \mathrm{C} 57 \mathrm{BL} / 6)$ & $\mathrm{EPM}, \mathrm{LD}, \mathrm{OF}$ & [48] \\
\hline & KO & $\operatorname{Mix}(129, \mathrm{C} 57 \mathrm{BL} / 6)$ & $\mathrm{OF}$ & {$[22]$} \\
\hline & $\mathrm{KO}$ & $\operatorname{Mix}(129, \mathrm{C} 57 \mathrm{BL} / 6)$ & EPM,OF & [3] \\
\hline Dopamine $_{4}$ receptor & $\mathrm{KO}$ & $\operatorname{Mix}(129, \mathrm{C} 57 \mathrm{BL} / 6)$ & $\mathrm{OF}$ & {$[26]$} \\
\hline Endothelial nitric oxide synthase & $\mathrm{KO}$ & $\mathrm{C} 57 \mathrm{BL} / 6$ & EPM, OF & {$[28]$} \\
\hline Estrogen receptor alpha & $\mathrm{KO}$ & Mix $(129, \mathrm{C} 57 \mathrm{BL} / 6)$ & $\mathrm{LD}$ & {$[64]$} \\
\hline Fyn protooncogene & $\mathrm{KO}$ & $\operatorname{Mix}(129, \mathrm{C} 57 \mathrm{BL} / 6)$ & EPM, LD, OF & [61] \\
\hline \multirow{2}{*}{ GABAa receptor $\gamma_{2}$} & $\mathrm{KO}$ & $\operatorname{Mix}(129, \mathrm{C} 57 \mathrm{BL} / 6)$ & $\mathrm{EPM}, \mathrm{LD}, \mathrm{FE}$ & {$[24]$} \\
\hline & $\mathrm{KO}$ & $\operatorname{Mix}(129, \mathrm{C} 57 \mathrm{BL} / 6)$ & $\mathrm{EPM}$ & {$[42]$} \\
\hline \multirow[t]{2}{*}{ Glutamic acid decarboxylase } & $\mathrm{KO}$ & $\mathrm{C} 57 \mathrm{BL} / 6$ & EPM & [47] \\
\hline & $\mathrm{KO}$ & ? & LD & {$[83]$} \\
\hline \multirow{4}{*}{ 5-hydroxytryptamine ${ }_{1 \mathrm{a}}$ receptor } & $\mathrm{KO}$ & $\operatorname{Mix}(129$, C57BL/6) & EPM & [39] \\
\hline & $\mathrm{KO}$ & 129 & EPM & {$[70]$} \\
\hline & $\mathrm{KO}$ & Mix (C57BL/6, Swiss) & OF & [68] \\
\hline & $\mathrm{KO}$ & 129 & EPM & [69] \\
\hline Interferon $\gamma$ & $\mathrm{KO}$ & $\operatorname{Mix}(129$, C57BL/6) & EPM & {$[51]$} \\
\hline Interleukin 6 & $\mathrm{KO}$ & $\operatorname{Mix}(129, \mathrm{C} 57 \mathrm{BL} / 6)$ & EPM & [2] \\
\hline MAS oncogene & $\mathrm{KO}$ & $\operatorname{Mix}(129, \mathrm{C} 57 \mathrm{BL} / 6)$ & EPM & {$[88]$} \\
\hline Midkine & $\mathrm{KO}$ & 129 & EPM & {$[62]$} \\
\hline Neural cell adhesion molecule & $\mathrm{KO}$ & $\operatorname{Mix}(129, \mathrm{C} 57 \mathrm{BL} / 6)$ & LD & {$[83]$} \\
\hline \multirow[t]{3}{*}{ Neuropeptide Y } & $\mathrm{Tg}$ & $\operatorname{Mix}(\mathrm{C} 57 \mathrm{BL} / 6, \mathrm{DBA} / 2)$ & EPM & [44] \\
\hline & $\mathrm{KO}$ & $\operatorname{Mix}(129, \mathrm{C} 57 \mathrm{BL} / 6)$ & EPM & [67] \\
\hline & $\mathrm{KO}$ & ? & AS, EPM & [4] \\
\hline Orphanin FQ & $\mathrm{KO}$ & $\operatorname{Mix}(129, \mathrm{C} 57 \mathrm{BL} / 6)$ & EPM, OF, LD & {$[50]$} \\
\hline Preproenkephalin & $\mathrm{KO}$ & $\operatorname{Mix}(129, \mathrm{CD} 1)$ & $\mathrm{EPM}$ & [49] \\
\hline Puromycin-sensitive aminopeptidase & $\mathrm{KO}$ & $\mathrm{BALB} / \mathrm{c}$ & EPM & [66] \\
\hline Single-minded 2 & $\operatorname{Tg}$ & $?$ & EPM & {$[20]$} \\
\hline Tumor necrosis factor- $\alpha$ & $\mathrm{Tg}$ & $\operatorname{Mix}(\mathrm{C} 57 \mathrm{BL} / 6, \mathrm{CBA})$ & $\mathrm{LD}$ & {$[27]$} \\
\hline
\end{tabular}

Abbreviations used: AS, acoustic startle; DF, defensive withdrawal; EPM, elevated plus-maze; FE, free-exploration; LD, light/dark; OF, open-field; SIH, stress-induced hyperthermia; KO, knock-out; tg, transgenic mice overexpressing a target protein

ing factor (CRF), neuropeptide $\mathrm{Y}$ ) in emotional processes, many others include genes that have not been shown to be involved in anxiety behaviors earlier (e.g. fyn protooncogene, MAS oncogene, tumor necrosis factor- $\alpha$ ).

In 1998, Ramboz and colleagues claimed that mice lacking the $5-\mathrm{HT}_{1 \mathrm{~A}}$ receptor by homologous recombination may represent a valid animal model of anxietyrelated disorder since they showed increased emotionality in the elevated plus-maze test [70]. This finding was confirmed by several other studies which demonstrated that knockout mice lacking the $5-\mathrm{HT}_{1 \mathrm{~A}}$ receptors display increases in fear-related behaviors in the elevated plus-maze and several other procedures (open-field, stress-induced hyperthermia) [39,68,69]. CRF has also been largely the focus of gene targeting in order to generate animals that show increased anxiety, and thus may provide a 'pathological' model of anxiety. For example, it was demonstrated that CRF transgenic mouse lines overexpressing CRF exhibited a behavioral state resembling that produced by anxiety in the elevated plus-maze and the light/dark tests [82]. Moreover, three recent studies reported that male, but not female, $\mathrm{CRF}_{2}$ receptor-deficient mice exhibit enhanced anxious behavior in several tests of anxiety, including the elevated plus-maze, the light/dark and the open-field tests $[3,22,48]$. Finally, CRF-binding protein-deficient mice were shown to exhibit a significant increase in a fear-related behavior in the elevated plus-maze, open-field and defensive withdrawal tests [46,71]. The well acknowledged involvement of GABA in the regulation of emotional processes and the anxiety-modulating action of 
$\mathrm{BZ}$ receptor ligands, has led to the development of mice displaying a deficit in the $\gamma_{2}$ subunit of the $\mathrm{GABA}_{\mathrm{A}}$ receptor, which has been shown to be essential in mediating the modulatory actions of BZs. Behavioral observations showed that these mice exhibit anxiogeniclike responses in several models based on the exploration of aversive areas [23,42]. Studies using pharmacological tools have shown that the neuroactive peptide NPY may play a critical role in anxiety. Indeed, the central infusion of the neuroactive peptide NPY and NPY fragments selective for the $Y_{1}$ receptor was demonstrated to elicit anxiolytic-like effects in a variety of tests, whereas the local application of $Y_{1}$ receptor antagonists produce the opposite action [32]. On the basis of these findings, several research groups created mutant mice lacking the gene for NPY $[4,67]$. Data from behavioral tests revealed that these mice have an anxiogenic-like phenotype.

These genetic animal models of anxiety have at first glance clear advantages over 'state' anxiety models in which baseline levels of anxiety of a 'normal' subject are increased artificially by exposure to aversive stimuli. They may provide a unique opportunity to study human anxiety and emotional disorders. Unfortunately, all these genetic models are based on the deletion of a single gene, and it is now clear that the modulation anxiety processes involves multiple genes. There is no doubt for example that the $5-\mathrm{HT}_{1 \mathrm{~A}}$ receptor plays a role in anxiety, but it is excessive to describe mice lacking this receptor as 'an animal model of anxiety-related disorder' [70] since it is by far not the only target involved in the regulation of emotional processes. Another problem with these mouse models of 'pathological' anxiety is that the measure of anxiety has been performed in a few tests of anxiety only. Among the 38 references listed in Table 2, 27 (i.e. 71\%) used the elevated plus-maze, and 35 (i.e. 92\%) employed exploration tests only. In view of the above concern regarding the elevated plus-maze, experiments with mutant mice in this test require extreme caution when interpreting the data. It is possible that in a few instances, responses exhibited by these mice may relate to behavioral processes unrelated to anxiety. Finally, most of the mutant mice studies have been undertaken using only one genetic background, usually a mixed C57B1/6 and 129 F2 strain. It would be useful to undertake behavioral studies using more then one strain, for example including a strain exhibiting a high emotionality level and a strain displaying a low emotionality. Indeed, strain differences in emotionality have repeatedly been reported (see next paragraph). Furthermore, most mutant studies used embryonic stem cells from a 129 substrain, and then cross chimaeric animals with C57B1/6 mice. Homozygous for the targeted mutation are then generated by producing an F2 intercross with a part of the genetic background of 129 and another part of $\mathrm{C} 57 \mathrm{Bl} / 6$. In some cases, mutant animals are then backcrossed to 129 or $\mathrm{C} 57 \mathrm{Bl} / 6$ for two to five generations, rarely more. Unfortunately, some confounding effects may be related to the 129 substrain genes flanking the target locus which are present in the mutant animal and not in the corresponding wildtype mice (see Gerlai [29] for further details).

The use of strains of mice displaying spontaneously elevated emotionality or mice selected for their high levels of anxiety may circumvent some of the problems encountered with the above-mentioned mutant mouse models. Such animals would exhibit increased anxiety not because of the deletion of a single gene, but because it is an enduring feature of a strain or an individual, probably involving multiple genetic and environmental factors. While several animal models of 'trait' anxiety have been described in rats (e.g. Wistar-Kyoto [31], Roman line [18], Sardinian alcohol-preferring [21]), there is only one mouse strain that has shown consistently higher levels of anxiety when compared with other strains, namely the BALB/c line. For example, Makino et al. [56] demonstrated that BALB/c mice showed strong and long-lasting stretching immediately after their introduction into the open-field, while C57BL/6 and DBA/2 mice never displayed such behavior. Instead, they immediately started to move around. These authors interpreted their findings in terms of 'emotional arousal', with the BALB/c strain being more 'anxious' than the two other lines. Moreover, using several tasks based on exploratory behavior (e.g. the light/dark choice test) we confirmed that BALB/c generally show a more pronounced reluctance to locomote in a novel area than do other inbred $(\mathrm{C} 57 \mathrm{BL} / 6, \mathrm{C} 3 \mathrm{H}$, CBA, DBA/2, NZB, SJL) and/or outbred (NMRI, Swiss) strains of mice [10,34]. Interestingly, unlike the other strains, BALB/c mice exhibit strong neophobic reactions when confronted simultaneously with a familiar and a novel compartment in the free-exploration test [33]. Based on the finding that no neurovegetative changes were apparent in mice that had free access to novelty when compared with the modifications induced by situations in which these animals were forced, the free-exploration test can be considered to be devoid of clear anxiogenic stimuli [60]. Consequently, the observation that $\mathrm{BALB} / \mathrm{c}$ mice display strong neophobic reactions in this procedure indicates that neophobia represents a constant feature of their behavior. The reasons for the differences in the level of fearfulness between $\mathrm{BALB} / \mathrm{c}$ mice and the other strains remain largely unknown, but certainly include many factors such as life history, test situation or housing conditions. More importantly, these differences may be due to neuroanatomical, neurochemical or genetic factors. For example, it was reported that $\mathrm{BALB} / \mathrm{c}$ and $\mathrm{C} 57 \mathrm{BL} / 6$ mice differ in the density and/or the affinity of $\mathrm{BZ}$ receptors $[19,72]$. These authors showed that the affinity 
for $\mathrm{BZ}$ receptors is higher in $\mathrm{BALB} / \mathrm{c}$ than in $\mathrm{C} 57 \mathrm{BL} / 6$ mice, whereas the latter strain displays a greater density in $\mathrm{BZ}$ receptor sites than the former. However, this particularity is not limited to the BZ receptors. Indeed, electric footshock induces a higher increase in dopaminergic turnover in the prefrontal cortex of $\mathrm{BALB} / \mathrm{c}$ than in $\mathrm{C} 57 \mathrm{Bl} / 6$ mice [40]. Finally, this strain also exhibits some particular features in the sensitivity to anxiolytic agents. Indeed, it has a high sensitivity to the anxiolytic action of BZs [34] and low doses of the BZ receptor antagonist flumazenil induce an anxiolytic-like action in this strain [9]. Furthermore, naloxone, an opioid antagonist, blocks the anxiolytic-like action of BZs in SWISS and $\mathrm{C} 57 \mathrm{Bl} / 6$ mice, but not in $\mathrm{BALB} / \mathrm{c}$ mice, an effect probably related to abnormality in $\kappa$-opioidergic receptors $[1,5,8]$. These strain differences in the action of pharmacological agents also appear for measures not related to anxiety. For example, when compared with $\mathrm{C} 57 \mathrm{Bl} / 6$ mice, the BALB/c strain is very sensitive to the convulsant action of the $\mathrm{BZ}$ inverse agonist $\beta-\mathrm{CCM}$ [24]. In the conditioned place preference test, a model relevant for the study of the subjective properties of drugs, amphetamine, a psychostimulant, produced a positive reinforcing effects in $\mathrm{C} 57 \mathrm{Bl} / 6$ mice, while the opposite was observed in BALB/c mice [7]. Taken as a whole, these findings with $\mathrm{BALB} / \mathrm{c}$ mice strongly suggest that this strain may be considered as a realistic model of 'trait' anxiety, which is not only related to one particular target (as observed in targeted mutations), but to abnormalities in various neurotransmitter systems (GABAergic, dopaminergic, opioidergic, etc.).

In conclusion, while animal models of 'state' anxiety remain the mainstay of tests used in studies dealing with emotional processes, models of 'pathological' anxiety, which are in great part based on the use of gene targeting technology, are used increasingly. However, their usefulness as models of anxiety is limited since they are based on the deletion of a single gene, which alone can hardly account for a complex condition such as anxiety. Possibly, the use of inbred 'anxious' mouse strains, which show constant high levels of fearfulness, may provide models of anxiety that have greater face, construct and/or predictive validity than 'state' or single-gene deletion models of anxiety.

\section{References}

[1] Agmo A, Belzung C, Deloire X, Grassin M, Lewis S. Blockade of anxiolytic-like actions of chlordiazepoxide by naloxone in the elevated plus-maze: comparisons between Swiss, C57BL/6 and BALB/c mice. Psychobiology 1999;27:105-13.

[2] Armario A, Hernandez J, Bluethmann H, Hidalgo J. IL-6 deficiency leads to increased emotionality in mice: evidence in transgenic mice carrying a null mutation for IL-6. J Neuroimmunol 1998;92:160-9.
[3] Bale TL, Contarino AB, Smith GW, Chan R, Gold LH, Sawchenko PE, Koob GF, Vale WW, Lee KF. Mice deficient for corticotropin-releasing hormone receptor-2 display anxiety-like behaviour and are hypersensitive to stress. Nat Genet 2000;24:410-4.

[4] Bannon AW, Seda J, Carmouche M, Francis JM, Norman MH, Karbon B, McCaleb ML. Behavioral characterization of neuropeptide Y knockout mice. Brain Res 2000;868:79-87.

[5] Belzung C, Agmo A. Naloxone blocks anxiolytic-like effects of benzodiazepines in Swiss but not in BALB/c mice. Psychopharmacology 1997;132:195-201.

[6] Belzung C, Agmo A. Naloxone potentiates the effects of subeffective doses of anxiolytic agents in mice. Eur $\mathrm{J}$ Pharmacol 1997;323:133-6.

[7] Belzung C, Barreau S. Differences in drug-induced place conditioning between $\mathrm{BALB} / \mathrm{c}$ and $\mathrm{C} 57 \mathrm{Bl} / 6$ mice. Pharmacol Biochem Behav 2000;65:419-23.

[8] Belzung C, Dubreuil D. Naloxone potentiates the anxiolytic but not the amnestic action of chlordiazepoxide in C57BL/6 mice. Behav Pharmacol 1998;9:691-8.

[9] Belzung C, Leguisquet AM, Crestani F. Flumazenil induces benzodiazepine partial agonist-like effects in BALB/c but not C57BL/6 mice. Psychopharmacology 2000;148:24-32.

[10] Beuzen A, Belzung C. Link between emotional memory and anxiety states: a study by principal component analysis. Physiol Behav 1995;58:111-8.

[11] Bhattacharya SK, Acharya SB. Further investigations on the anxiogenic action of isatin. Biogenic Amines 1993;9:5-6.

[12] Blanchard RJ, Blanchard DC. Affect and aggression: an animal model applied to human behavior. In: Blanchard RJ, Blanchard DC, editors. Advances in the study of aggression. Orlando: Academic Press, 1984:1-62.

[13] Blanchard RJ, Blanchard DC, Rodgers J, Weiss SM. The characterization and modelling of antipredator defensive behavior. Neurosci Biobehav Rev 1990;14:463-72.

[14] Blanchard RJ, Griebel G, Henrie JA, Blanchard DC. Differentiation of anxiolytic and panicolytic drugs by effects on rat and mouse defense test batteries. Neurosci Biobehav Rev 1997;21:783-9.

[15] Caldji C, Tannenbaum B, Sharma S, Francis D, Plotsky PM, Meaney MJ. Maternal care during infancy regulates the development of neural systems mediating the expression of fearfulness in the rat. Proc Natl Acad Sci USA 1998;95:5335-40.

[16] Canguilhelm G. Le normal et le pathologique. Paris: PUF, 1999.

[17] Calatayud F, Belzung C. Emotional reactivity in mice: a case of non-genetic heredity? Physiol Behav, 2001;in press.

[18] Chaouloff F, Castanon N, Mormede P. Paradoxical differences in animal models of anxiety among the Roman rat lines. Neurosci Lett 1994;182:217-21.

[19] Chapouthier G, Bondoux D, Martin B, Desforges C, Launay JM. Genetic difference in sensitivity to beta-carboline: evidence for the involvement of brain benzodiazepine receptors. Brain Res 1991;553:342-6.

[20] Chrast R, Scott HS, Madani R, Huber L, Wolfer DP, Prinz M, Aguzzi A, Lipp HP, Antonarakis SE. Mice trisomic for a bacterial artificial chromosome with the single-minded 2 gene (SIM2) show phenotypes similar to some of those present in the partial trisomy 16 mouse models of down syndrome. Hum Mol Genet 2000;9:1853-64.

[21] Colombo G, Agabio R, Lobina C, Reali R, Zocchi A, Fadda F, Gessa GL. Sardinian alcohol-preferring rats: a genetic animal model of anxiety. Physiol Behav 1995;57:1181-5.

[22] Coste SC, Kesterson RA, Heldwein KA, Stevens SL, Heard AD, Hollis JH, Murray SE, Hill JK, Pantely GA, Hohimer AR, Hatton DC, Phillips TJ, Finn DA, Low MJ, Rittenberg MB, Stenzel P, StenzelPoore MP. Abnormal adaptations to stress and impaired cardiovascular function in mice lacking corticotropinreleasing hormone receptor-2. Nat Genet 2000;24:403-9. 
[23] Crestani F, Lorez M, Baer K, Essrich C, Benke D, Laurent JP, Belzung C, Fritschy JM, Luscher B, Mohler H. Decreased $\mathrm{GABA}_{\mathrm{A}}$-receptor clustering results in enhanced anxiety and a bias for threat cues. Nat Neurosci 1999;2:833-9.

[24] Desforges C, Venault P, Dodd RH, Chapouthier G, Roubertoux PL. Carboline-induced seizures in mice: genetic analysis. Pharmacol Biochem Behav 1989;34:733-7.

[25] DSM-IV, Diagnostic and Statistical Manual of Mental Disorders, Fourth ed. Washington, DC: American Psychiatric Association, 1994.

[26] Dulawa SC, Grandy DK, Low MJ, Paulus MP, Geyer MA. Dopamine D4 receptor-knock-out mice exhibit reduced exploration of novel stimuli. J Neurosci 1999;19:9550-6.

[27] Fiore M, Alleva E, Probert L, Kollias G, Angelucci F, Aloe L. Exploratory and displacement behavior in transgenic mice expressing high levels of brain TNF-alpha. Physiol Behav 1998;63:571-6.

[28] Frisch C, Dere E, Silva MAD, Godecke A, Schrader R, Huston JP. Superior water maze performance and increase in fear-related behavior in the endothelial nitric oxide synthase-deficient mouse together with monoamine changes in cerebellum and ventral striatum. J Neurosci 2000;20:6694-700.

[29] Gerlai R. Gene-targeting studies of mammalian behavior: is it the mutation or the background genotype? Trends Neurosci 1996;19:177-81.

[30] Gogos JA, Morgan M, Luine V, Santha M, Ogawa S, Pfaff D, Karayiorgou M. Catechol- $O$-methyltransferase-deficient mice exhibit sexually dimorphic changes in catecholamine levels and behavior. Proc Natl Acad Sci USA 1998;95:9991-6.

[31] Goto SH, Conceicao IM, Ribeiro RA, Frussa Filho R. Comparison of anxiety measured in the elevated plus-maze, open-field and social interaction tests between spontaneously hypertensive rats and Wistar EPM-1 rats. Braz J Med Biol Res 1993;26:9659.

[32] Griebel G. Is there a future for neuropeptide receptor ligands in the treatment of anxiety disorders? Pharmacol Ther 1999;82:161.

[33] Griebel G, Belzung C, Misslin R, Vogel E. The free-exploratory paradigm: an effective method for measuring neophobic behaviour in mice and testing potential neophobia-reducing drugs. Behav Pharmacol 1993;4:637-44.

[34] Griebel G, Belzung C, Perrault G, Sanger DJ. Differences in anxiety-related behaviours and in sensitivity to diazepam in inbred and outbred strains of mice. Psychopharmacology 2000;148:164-70.

[35] Griebel G, Blanchard DC, Jung A, Blanchard RJ. A model of 'antipredator' defense in Swiss-Webster mice: effects of benzodiazepine receptor ligands with different intrinsic activities. Behav Pharmacol 1995;6:732-45.

[36] Griebel G. 5-Hydroxytryptamine-interacting drugs in animal models of anxiety disorders: more than 30 years of research. Pharmacol Ther 1995;65:319-95.

[37] Griebel G, Sanger DJ. The mouse defense test battery: an experimental model of different emotional states. In: Haug M, Whalen RE, editors. Animal Models of Human Emotion and Cognition. Washington, DC: American Psychological Association, 1999:75-85.

[38] Heinrichs SC, Min H, Tamraz S, Carmouche M, Boehme SA, Vale WW. Anti-sexual and anxiogenic behavioral consequences of corticotropin-releasing factor overexpression are centrally mediated. Psychoneuroendocrinology 1997;22:215-24.

[39] Heisler LK, Chu HM, Brennan TJ, Danao JA, Bajwa P, Parsons LH, Tecott LH. Elevated anxiety and antidepressant-like responses in serotonin 5-HT1A receptor mutant mice. Proc Nat Acad Sci USA 1998;95:15049-54.

[40] Herve D, Tassin JP, Barthelemy C, Blanc G, Lavielle S, Glowinski J. Difference in the reactivity of the mesocortical dopaminer- gic neurons to stress in the $\mathrm{BALB} / \mathrm{c}$ and $\mathrm{C} 57 \mathrm{BL} / 6$ mice. Life Sci 1979;25:1659-64.

[41] Hogg S. A review of the validity and variability of the elevated plus-maze as an animal model of anxiety. Pharmacol Biochem Behav 1996;54:21-30.

[42] Homanics GE, Harrison NL, Quinlan JJ, Krasowski MD, Rick CE, De Blas AL, Mehta AK, Kist F, Mihalek RM, Aul JJ, Firestone LL. Normal electrophysiological and behavioral responses to ethanol in mice lacking the long splice variant of the $\gamma 2$ subunit of the $\gamma$-aminobutyrate type A receptor. Neuropharmalogy 1999;38:253-65.

[43] Ichiki T, Labosky PA, Shiota C, Okuyama S, Imagawa Y, Fogo A, Niimura F, Ichikawa I, Hogan BL, Inagami T. Effects on blood pressure and exploratory behaviour of mice lacking angiotensin II type-2 receptor. Nature 1995;377:748-50.

[44] Inui A, Okita M, Nakajima M, Momose K, Ueno N, Teranishi A, Miura M, Hirosue Y, Sano K, Sato M, Watanabe M, Sakai T, Watanabe T, Ishida K, Silver J, Baba S, Kasuga M. Anxietylike behavior in transgenic mice with brain expression of neuropeptide Y. Proc Assoc Am Physicians 1998;110:171-82.

[45] Kaplan A. The Conduct of Inquiry. Methodology for Behavioral Sciences. Aylesbury, Buckinghamshire: International Textbook Company, 1973.

[46] Karolyi IJ, Burrows HL, Ramesh TM, Nakajima M, Lesh JS, Seong E, Camper SA, Seasholtz AF. Altered anxiety and weight gain in corticotropin-releasing hormone-binding protein-deficient mice. Proc Nat Acad Sci USA 1999;96:11595-600.

[47] Kash SF, Tecott LH, Hodge C, Baekkeskov S. Increased anxiety and altered responses to anxiolytics in mice deficient in the $65-\mathrm{kDa}$ isoform of glutamic acid decarboxylase. Proc Nat Acad Sci USA 1999;96:1698-703.

[48] Kishimoto T, Radulovic J, Radulovic M, Lin CR, Schrick C, Hooshmand F, Hermanson O, Rosenfeld MG, Spiess J. Deletion of $\mathrm{Crhr} 2$ reveals an anxiolytic role for corticotropin-releasing hormone receptor-2. Nat Genet 2000;24:415-9.

[49] Konig M, Zimmer AM, Steiner H, Holmes PV, Crawley JN, Brownstein MJ, Zimmer A. Pain responses, anxiety and aggression in mice deficient in pre-proenkephalin. Nature 1996;383:535-8.

[50] Köster A, Montkowski A, Schulz S, Stube EM, Knaudt K, Jenck F, Moreau JL, Nothacker HP, Civelli O, Reinscheid RK. Targeted disruption of the orphanin FQ/nociceptin gene increases stress susceptibility and impairs stress adaptation in mice. Proc Nat Acad Sci USA 1999;96:10444-9.

[51] Kustova Y, Sei Y, Morse HC Jr., Basile AS. The influence of a targeted deletion of the IFNgamma gene on emotional behaviors. Brain Behav Immun 1998;12:308-24.

[52] Ledent C, Vaugeois JM, Schiffmann SN, Pedrazzini T, El Yacoubi M, Vanderhaeghen JJ, Costentin J, Heath JK, Vassart G, Parmentier M. Aggressiveness, hypoalgesia and high blood pressure in mice lacking the adenosine A2a receptor. Nature 1997;388:674-8.

[53] Lee C, Rodgers RJ. Effects of buspirone on antinociceptive and behavioural responses to the elevated plus-maze in mice. Behav Pharmacol 1991;2:491-6.

[54] Lister RG. Ethologically-based animal models of anxiety disorders. Pharmacol Ther 1990;46:321-40.

[55] Lister RG. The use of a plus-maze to measure anxiety in the mouse. Psychopharmacology 1987;92:180-5.

[56] Makino J, Kato K, Maes FW. Temporal structure of open-field behavior in inbred strains of mice. Jpn Psychol Res 1991;33:145-52.

[57] McKinney WT. Animal models of depression: an overview. Psychiatr Dev 1984;2:77-96.

[58] McKinney WT Jr., Bunney WE Jr. Animal model of depression. I. Review of evidence: implications for research. Arch Gen Psychiatry 1969;21:240-8. 
[59] Micheau J, vanMarrewijk B. Stimulation of 5-HT1A receptors by systemic or medial septum injection induces anxiogenic-like effects and facilitates acquisition of a spatial discrimination task in mice. Prog Neuro Psych Biol Psych 1999;23:1113-33.

[60] Misslin R, Cigrang M. Does neophobia necessarily imply fear or anxiety? Behavioural Processes 1986;12:45-50.

[61] Miyakawa T, Yagi T, Watanabe S, Niki H. Increased fearfulness of Fyn tyrosine kinase deficient mice. Brain Res Mol Brain Res 1994;27:179-82.

[62] Nakamura E, Kadomatsu K, Yuasa S, Muramatsu H, Mamiya T, Nabeshima T, Fan QW, Ishiguro K, Igakura T, Matsubara S, Kaname T, Horiba M, Saito H, Muramatsu T. Disruption of the midkine gene (MDK) resulted in altered expression of a calcium binding protein in the hippocampus of infant mice and their abnormal behaviour. Genes Cells 1998;3:811-22.

[63] Nunes de Souza RL, CantodeSouza A, DaCosta M, Fornari RV, Graeff FG, Pela IR. Anxiety-induced antinociception in mice: effects of systemic and intra-amygdala administration of 8-OH-DPAT and midazolam. Psychopharmacology 2000;150:300-10.

[64] Ogawa S, Lubahn DB, Korach KS, Pfaff DW. Behavioral effects of estrogen receptor gene disruption in male mice. Proc Natl Acad Sci USA 1997;94:1476-81.

[65] Okuyama S, Sakagawa T, Chaki S, Imagawa Y, Ichiki T, Inagami T. Anxiety-like behavior in mice lacking the angiotensin II type-2 receptor. Brain Res 1999;821:150-9.

[66] Osada T, Ikegami S, TakiguchiHayashi K, Yamazaki Y, KatohFukui Y, Higashinakagawa T, Sakaki Y, Takeuchi T. Increased anxiety and impaired pain response in puromycin-sensitive aminopeptidase gene-deficient mice obtained by a mouse genetrap method. J Neurosci 1999;19:6068-78.

[67] Palmiter RD, Erickson JC, Hollopeter G, Baraban SC, Schwartz MW. Life without neuropeptide Y. Recent Prog Horm Res 1998;53:163-99.

[68] Parks CL, Robinson PS, Sibille E, Shenk T, Toth M. Increased anxiety of mice lacking the serotonin1A receptor. Proc Natl Acad Sci USA 1998;95:10734-9.

[69] Pattij T, Sarnyai Z, Brunner D, Olivier B. Does the 5-HT1A receptor knockout mouse have an anxious phenotype? Int $\mathbf{J}$ Psychopharmacol 2000;3(Suppl. 1):S275.

[70] Ramboz S, Oosting R, Amara DA, Kung HF, Blier P, Mendelsohn M, Mann JJ, Brunner D, Hen R. Serotonin receptor 1A knockout: an animal model of anxiety-related disorder. Proc Natl Acad Sci USA 1998;95:14476-81.

[71] Ramesh TM, Karolyi IJ, Nakajima M, Camper SA, Seasholtz AF. Altered physiological and behavioral responses in CRHbinding protein deficient mice. Soc Neurosci Abstr 1998;24:5055.

[72] Robertson HA. Benzodiazepine receptors in 'emotional' and 'non emotional' mice: comparison of four strains. Eur J Pharmacol 1979;56:163-6.

[73] Rodgers RJ, Cao BJ, Dalvi A, Holmes A. Animal models of anxiety: an ethological perspective. Braz J Med Biol Res 1997;30:289-304.
[74] Rodgers RJ, Cole JC. The elevated plus-maze: pharmacology, methodology and ethology. In: Cooper SJ, Hendrie CA, editors. Ethology and Psychopharmacology. Chichester: Wiley, 1994:944.

[75] Rodgers RJ, Cole JC, Cobain MR, Daly P. Anxiogenic-like effects of fluprazine and eltoprazine in the mouse elevated plusmaze: Profile comparisons with 8-OH-DPAT, CGS 12066B, TFMPP and mCPP. Behav Pharmacol 1992;3:621-34.

[76] Rodgers RJ, Johnson NJT. Factor analysis of spatiotemporal and ethological measures in the murine elevated plus-maze test of anxiety. Pharmacol Biochem Behav 1995;52:297-303.

[77] Ross SA, Wong JYF, Clifford JJ, Kinsella A, Massalas JS, Horne MK, Scheffer IE, Kola I, Waddington JL, Berkovic SF, Drago J. Phenotypic characterization of an alpha(4) neuronal nicotinic acetylcholine receptor subunit knock-out mouse. J Neurosci 2000;20:6431-41.

[78] Rupniak NM, Kramer MS. Discovery of the antidepressant and anti-emetic efficacy of substance $\mathrm{P}$ receptor (NK1) antagonists. Trends Pharmacol Sci 1999;20:485-90.

[79] Sanger DJ, Perrault G, Morel E, Joly D, Zivkovic B. Animal models of anxiety and the development of novel anxiolytic drugs. Prog Neuro Psychopharmacol Biol Psychiatry 1991;15:205-12.

[80] Seale TW, Niekrasz I, Garrett KM. Anxiolysis by ethanol, diazepam and buspirone in a novel murine behavioral assay. NeuroReport 1996;7:1803-8.

[81] Skinner, B.F., Contingencies of Reinforcement: a theoretical analysis, Appleton-Century-Crofts, New-York, 1969.

[82] Stenzel-Poore MP, Duncan JE, Rittenberg MB, Bakke AC, Heinrichs SC. CRH overproduction in transgenic mice: behavioral and immune system modulation. Ann NY Acad Sci 1996;780:36-48.

[83] Stork O, Welzl H, Wotjak CT, Hoyer D, Delling M, Cremer H, Schachner M. Anxiety and increased 5-HT1A receptor response in NCAM null mutant mice. J Neurobiol 1999;40:343-55.

[84] Treit D. Animal models for the study of anti-anxiety agents: a review. Neurosci Biobehav Rev 1985;9:203-22.

[85] Tsang CF, Wilkinson GR. Diazepam disposition in mature and aged rabbits and rats. Drug Metab Dispos 1982;10:413-6.

[86] Tweed JL, Schoenbach VJ, George LK, Blazer DG. The effects of childhood parental death and divorce on six-month history of anxiety disorders. Br J Psychiatry 1989;154:823-8.

[87] Vasar E, Koks S, Beljajev S, Abramov U, Koovit I, Matsui T. CCKB receptor knockout mice: gender related behavioural differences. Eur Neuropsychopharmacol 2000;10(Suppl. 2):S69.

[88] Walther T, Balschun D, Voigt JP, Fink H, Zuschratter W, Birchmeier C, Ganten D, Bader M. Sustained long term potentiation and anxiety in mice lacking the Mas protooncogene. J Biol Chem 1998;273:11867-73.

[89] Weiss SM, Lightowler S, Stanhope KJ, Kennett GA, Dourish CT. Measurement of anxiety in transgenic mice. Rev Neurosci 2000;11:59-74.

[90] Willner P, Muscat R, Papp M. Chronic mild stress-induced anhedonia: a realistic animal model of depression. Neurosci Biobehav Rev 1992;16:525-34. 